\title{
Christian Mysticism: A Meta-Theoretical Approach - Part I
}

Herman J. Pietersen

\author{
Professor, University of Limpopo, Turfloop Campus 0727, Republic of South Africa \\ herman.pietersen@ul.ac.za
}

\section{Doi:10.5901/mjss.2014.v5n16p473}

\begin{abstract}
In the current paper (Part I) a previously developed theory of fundamental orientations or modalities of mind is presented, together with a condensed overview of the nature and characteristics of Christian mysticism. The aim is to demonstrate the applicability of the theory to Christian mystical thought. The paper includes a selection of exemplars of Christian mysticism that represent each of the four archetypal orientations of the mind (types I, II, III and IV), and that were selected for discussion. The analysis is presented in three separate papers. In the second paper (Part II) speculative mysticism (Type I) and systematic mysticism (Type II) are reviewed as indicative of an objectivist tendency in Christian mystical thought. In the third paper (Part III) poetical mysticism (Type III) and pragmatic mysticism (Type IV) are discussed and shown to be representative of the subjectivist inclination in the writing of mystical theologians.
\end{abstract}

Keywords: Meta-theory, speculative mysticism, systematic mysticism, poetical mysticism, pragmatic mysticism.

\section{Introduction}

A meta-theory was developed that, in a coordinated manner, brought together axiomatic intellectual distinctions or world views that constantly re-surface in human thought. Although these elements have long been part of the history of thought, a comprehensive and integrative framework has been lacking. The aim was to redress this shortcoming by proposing an evidence-supported perspective on basic characteristics or modalities of the human intellect.

For this purpose an extensive study of various bodies of scholarly literature was conducted. The outcome was the identification and delineation of a number of root intellectual orientations or ways of looking at and trying to make sense of life and world. The meta-theory was subsequently tested for its conceptual plausibility and evidentiary support across a wide range of scholarly disciplines, thinkers, topics and cultures. (Pietersen, 2011; Pietersen, 2014).

The present paper extends the application of the framework by showing that basic modalities of the mind also manifest themselves in Christian mystical thought. Figure 1 shows four orientations in human thought that are the result of a combination of two epistemological and two ontological stances, namely: objectivist-empyrean (type I); objectivistempiricist (type II); subjectivist-empiricist (type III), and the subjectivist-empyrean (type IV).

This is followed in Figures 2, 3, 4 and 5 by a description of characteristic elements of each of the basic modalities in human thought. In essence, each of the primary orientations addresses a different question, namely: (a) what is this? (Type II); (b) what is behind this? (Type I); (c) what is wrong / wonderful about this? what's the story? (Type III); (d) what should be done about this? (Type IV).

\section{Main propositions}

The main propositions or theses of the theory are as follows:

a) Fundamental orientations of mind predetermine the type of ideas, theories, "ways" of making sense of and dealing with the world.

b) Each orientation or modality of mind co-exists with other modes in a dynamic mutuality of conflict and complementariness.

c) Thought products (individually or collectively) reflect different mixes of the basic orientations, although dominant (primary) tendencies prevail as a result of root "preferences". No thinker functions entirely within a single (primary) mode of thought, but also in varying degrees interfaces with directly adjacent (secondary) modes. Tertiary orientations also manifest in each intellectual product, either in a conflicting, suppressed or underrepresented manner. 
Figure 1: The four orientations in human thought

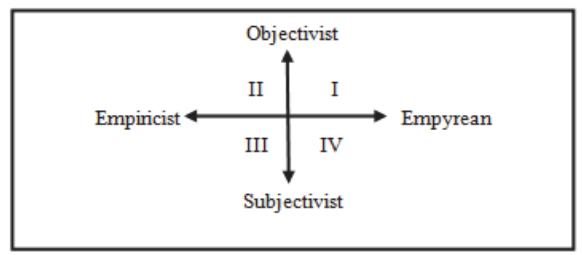

Figure 2: Objectivist-empyrean (type I) elements

- Emphasize reason (rationality)

- Impersonal

- Theoretical/integrative

- Macroscopic focus

- Comprehensive understanding

- Concerned with possible ideas

- To penetrate the deepest essentials and mysteries of life/world.

Figure 3: Objectivist-empiricist (type II) elements

- Emphasize reason (rationality)

- Impersonal

- Systematic-analytic

- Microscopic focus

- Detailed explanation

- Concerned with verifiable ideas

- To systematically analyze, order, predict and control life/world

Figure 4: Subjectivist-empiricist (type III) elements

- Emphasize values (humanism)

- Personal-engaged

- Experiential

- Poetic-particular-critical

- 'Feeling with' (solidarity)

- Concerned with individuals (the particularized other)

- To praise, eulogize, tell inspiring stories or To unmask, debunk, criticize and tell 'sad' stories

d) Together, the different modes of thought form a unity or whole with each giving meaning to the other and with each dependent on the existence of its opposite mode.

e) Attempted dominance by one modality of mind inevitably leads to countervailing reactions in other realms of thought. Adherents of highly divergent (directly opposing) orientations will more likely experience mutual misunderstanding, disaffection and even potentially irreconcilable beliefs and convictions.

f) Knowledge endeavours in the world at large, in different cultures, disciplines and traditions of thought, and at different levels of analysis, show similarity in terms of underlying modalities of mind.

Figure 5: Subjectivist-empyrean (type IV) elements

- Emphasize values (humanism)

- Communal-engaged

- Conceptual

- Ideological-universal-reformist

- 'Feeling for' (development, becoming)

- Concerned with society (the generalized other)

- To change, renew and re-engineer life / world / society according to valued ideals 
g) The limitations of one modality of mind are complemented by the strengths of others, especially its diagonally opposite mode.

\section{The Nature of Christian Mysticism}

Mysticism may perhaps most economically be defined as being about a special or 'secret' knowledge of the transcendent. For Underhill mysticism is: "...the expression of the innate tendency of the human spirit towards complete harmony with the transcendental order." (Underhill, 1930: 8). For another leading scholar on Christian mysticism, the term elicits different meanings for different people. For some it denotes something strange and esoteric, while: "Others see mysticism as the hidden core at the heart of all religions." (McGinn, 2006: xiii).

It is a premise of mystical thought and writing that however critical one may be about the concept, all human beings have the potential for mystical experiences, though for many it may be rather fleeting. An early scholar on Christian mysticism expresses it as follows: "Few people pass through life without knowing what it is to be at least touched by this mystical feeling. He who falls in love with a woman...he who falls in love with the Holy, or as we say 'undergoes conversion': all these have truly known for an instant something of the secret of the world." (Underhill, 1930: 71).

The word "mystical" (meaning "hidden," in Greek) has been in use since at least the second century CE by Christians, in reference to: "...the secret realities of their beliefs, rituals, and practices, especially to the "mystical meaning" of the Bible, that is, the inner message about attaining God that may be found beneath the literal sense of the scriptural texts and stories." (McGinn, 2006: xiv). Hence, for Christian mystics the Bible and especially Solomon's Song of Songs, is a central point of reference. (McGinn, 2006: 3, 4). A summary description of essential elements or characteristics of Christian mysticism is provided in Figure 6 below.

The mystical life is a very personal attempt to achieve union with God through various strenuous physical and mental experiences and events. The striving of the mystic is to become fully 'joined' or 'merged' with the One. During the final stage of the mystic process or journey: "...man's being is so penetrated with the divine substance that he loses himself therein, as a drop of water is lost in a cask of strong wine." (McGinn, 2006: 82).

The mystic has an unusually deep and intense desire, accompanied by a gradual but progressive denial of the Self, to find loving fulfilment and union in God, who is never regarded as mere objective reality of all that is: "Mystic Love is a total dedication of the will; the deep-seated desire and tendency of the soul towards its Source." (McGinn, 2006: 83).

Figure 6: Characteristics of Christian mysticism (McGinn, 2006: xvii, 78, 79)

1. It has always been part of the world religions - not a religion in itself.
2. It is essentially a process, an itinerary or journey to God.
3. Union (unio mystica) is an important goal of the mystical life.
4. It uses intensely personal language.
5. It concerns 'new ways of knowing and loving' God.
6. The essence of the mystical life is that of a personal transformation.
7. True mysticism is active and practical, not passive and theoretical.
8. Its aims are wholly transcendental and spiritual.
9. This One (God) is for the mystic, not merely the reality of all that is, but also a living and personal
'object of love'; never an object of exploration and contemplation only.
10. Union with God is reached through an onerous process of both pleasurable and painful
experiences, often referred to as the Mystic Way.

It should be mentioned that Christian mystics (with the exception of free-thinking, radical individuals during the Middle Ages and late medieval times) never denied, attacked or rejected the doctrines and authority of the Church. Meister Eckhart (and about four centuries later, also Madame Guyon), for instance, was eager to re-interpret and offer explanations of his ideas and statements should they be found to be contrary to the official position (parts of his work were indeed declared heretical two years after his death). Underhill observes that: "It is significant that the greatest mystics in all communions have ...been most eager to submit their soaring intuitions to the witness of their Scriptures or the corporate feeling of their church." (Underhill, 1920: 25).

The increasing appearance of mysticism in thirteenth and fourteenth century Europe may be ascribed to a number of causes or events over a period of time. One such was the growing reaction among the people against the abuses, greed and corruption of the Church hierarchy. Those with a very 'independent and critical spirit,' became known as the 
'Brethren and Sisters of the Free Spirit' and: "...were burned in batches at Cologne and elsewhere..." (Inge, 1904: 5).

Other factors were: the devastating effect of the Black Death; the dire economic and social consequences of thousands of Europe's productive male population joining the Crusades, many of whom never returned. This resulted in many women becoming mendicants (beggars) with the better educated class (especially in Germany) forming themselves into charitable orders known as the 'Beguines' (female) and 'Beghards' for their male counterparts.

Under these general conditions of extreme uncertainty and hardship, people felt the need for a deeper and more meaningful spiritual life, hence the increasing rise to prominence of mysticism. Inge succinctly describes the state of mind of these people: "Theirs was an intensely inward religion, based on the longing of the soul for immediate access to God." (Inge, 1904: 4).

To the mystic the journey to God involves both knowledge and love. However, in conformity with the poeticalromantic mind-set (type III) of mysticism generally, loving God is more important than knowledge of God (McGinn, 2006: 251). But, of course, in the history of mysticism the relationship between these two aspects have varied. Eckhart's mysticism, for instance, is generally acknowledged to be speculative and philosophically inclined (type I). On the other hand, the approaches of the English mystic, Richard Rolle and Henry Suso, the German mystic, are about their very ardent love of and seeking of God, which they narrate in a highly expressive, poetical manner (type III).

The true mystic is a creative artist whose achievements rival those of other creative expressions of the human spirit, and whose outpourings involve both the intellect and the imagination: "Sometimes the two aspects, personal and impersonal, are woven together by the poet and then it is that we come nearest to an understanding of the full experience he is trying to express..." (Underhill, 1920: 46, 47).

From the meta-theoretical point of view, it is interesting to note the distinction that is made between the empyrean and empiricist modalities of mind. Underhill distinguishes between: "...those who are temperamentally inclined to that pure contemplation which "has no image." (Underhill, 1920: 490). and those who are: "...naturally inclined to visualization, who tends to translate his supersensual experience into concrete, pictorial images; into terms of colour and of form." (Underhill, 1920: 49).

In her attempt to more clearly describe the mystic, Underhill (1930) also provides an informative comparison between magic (the precursor of science in the type II mode) and mysticism (the type III mode). Figure 7 presents a schematic summary.

Figure 7: Magic and mysticism compared (Underhill, 1930: 69, 70)

\begin{tabular}{|l|l|}
\hline Way of Magic & Way of Mysticism \\
\hline Magic wants to get & Mysticism wants to give \\
\hline $\begin{array}{l}\text { Will unites with the intellect in an impassioned desire for } \\
\text { supersensible knowledge. }\end{array}$ & $\begin{array}{l}\text { Will is united with the emotions in an impassioned desire to } \\
\text { transcend the sense-world. }\end{array}$ \\
\hline $\begin{array}{l}\text { The intellectual, aggressive, and scientific temperament } \\
\text { (movement of the mind) }\end{array}$ & The poetic and religious temperament (movement of the heart) \\
\hline Self-seeking transcendentalism & Self-giving transcendentalism \\
\hline
\end{tabular}

Mysticism, therefore, involves a deep psychological experience and organizing, more correctly: re-organizing or transformation, of the whole self and of the mystic's personal identity. A mystic who has travelled far enough on the journey to God is never the same person again.

\section{The Mystic Way}

The life of the mystic typically oscillates between various stages of development and progress (at times also regress) on the way to God, and also between states of intense pleasure and pain. The mystic consciousness reflects (in a metatheoretically recognizable manner) two basic ways of apprehending the truth and reality of God: "...the eternal and temporal, transcendent and immanent, absolute and dynamic aspects of Truth. They comprise the twofold knowledge of a God Who is both Being and Becoming near and far: pairs of opposites which the developed mystical experience will carry up into a higher synthesis..." (Underhill, 1930: 181).

Underhill's analysis abundantly reflects the archetypal distinctions between the empyrean and empirical, and between the objectivist and subjectivist orientations of the mind. Figure 8 shows the kind of meta-theoretical contrasts evidenced in her work. By way of summarizing Underhill's detailed analysis and discussion in her book Mysticism: $A$ study in the nature and development of spiritual consciousness (1930). Figure 9 shows five distinguishable and typical 
stages or states of mind of the Mystic Way. They are: awakening, purgation, illumination, final purgation and union.

Figure 8: Bifurcations in mystical experiences (Underhill, 1930: 181 - 184)

\begin{tabular}{|l|l|}
\hline Subjectivist-Immanent & Objectivist-Transcendent \\
\hline A mental state that governs the symbolic systems of the mystic. & A mental state that objectivizes reality as a place. \\
The individual appeal of an immediate 'presence.' & The appeal of a formless, ineffable vision. \\
The self awakens to that which is within. & An apprehension of splendour without. \\
The self awakens to the personal, not a cosmic relation. & The self reacts with awe and rapture rather than intimate affection. \\
\hline
\end{tabular}

In the first stage the self:"... awakes to that which is within, rather than to that which is without: to the immanent [the experiential] not the transcendent [the empyrean] God, to the personal [subjectivist] not the cosmic relation [objectivist]." (Underhill, 1930: 182).

In support of the schematic in Figure 9, a short description of each of the elements or mental states in the progressive unfolding of the Mystic Way is presented below:

1. Awakening of the self to the Divine Reality. (Underhill, 1930: 157)

This is characterized by: "The initial, overwhelming, experience of the ineffable which is accompanied by intense feelings of "joy and exaltation."' (Underhill, 1930: 157).

2. First purgation stage. (Underhill, 1930: 157)

The self realizes its finiteness and imperfection and engages in a process of cleansing.

It is a state of pain and effort, typically accompanied by two processes, namely: negative purification and positive purification.

a) Negative purification or 'self-stripping.' (Underhill, 1930: 189). It is, firstly, a process of detachment, consisting of 'chastity' or poverty (denial and suppression) of the senses and desires; secondly, in following the virtue of obedience, the self strives for 'poverty of the will' and 'self-abnegation.' (Underhill, 1930: 190).

b) Positive purification or 'character adjustment.' (Underhill, 1930: 189). It is a process of mortification consisting of a 'deliberate recourse to painful experiences and difficult tasks' (Underhill, 1930: 190) which aims to 'kill the old self' so that 'the new man may live and breathe.' (Underhill, 1930: 201).

3. Illumination or the 'first mystic life.' (Underhill, 1930: 158)

In this stage the mystic experiences a mental state of great happiness accompanied by a 'sense of divine Presence, but not yet true union.' (Underhill, 1930: 158). It is a state of 'loving and joyous relation between the Absolute and self' (Underhill, 1930: 216), yet the 'individuality of the subject remains separate and intact.' (Underhill, 1930: 227). It is characterized by various ecstasies, of which two main types (resulting from temperamental differences) are described: the 'rapture of Feminine Weakness' [note the gender bias] and the 'rapture of pure intellectual vision.' (Underhill, 1930: 331).

4. Final purgation or 'second mystic life.' (Underhill, 1930: 158)

This is the stage of supreme mental discomfort and anguish (which may last for months, even years), variously described as: 'the Dark Night of the Soul'; 'the Divine Absence'; 'a Spiritual Crucifixion' and of the 'surrender of the Self and the Will.' (Underhill, 1930: 349). Here the 'self must lose to find and die to live.' (Underhill, 1930: 368). Two possible reactions characterize this stage, namely: the emotional ('the anguish of the lover who has suddenly lost the Beloved') and the intellectual ('a darkness and confusion that overwhelms everything else'). (Underhill, 1930: 355).

5. Union of Self with God. (Underhill, 1930: 158)

In this, final, stage the mystic achieves his/her original aim and becomes 'one with the Absolute life.' (Underhill, 1930: 158). It is a state characterized by: 'equilibrium, peaceful joy, enhanced powers, intense certitude.' (Underhill, 1930: 158).

Here, again, two ways (based on temperament) are distinguished: the Intimate-Personal which speaks of 'consummation of communion' and the 'spiritual marriage of the soul with God' (Underhill, 1930: 380), and the Transcendent-Metaphysical state, characterized by 'the attainment of the absolute' (deification) and of 'utter transmutation of self in God.' (Underhill, 1930: 380). 
Figure 9: The five stages of the Mystic Way (Underhill, 1930: 157 - 389)

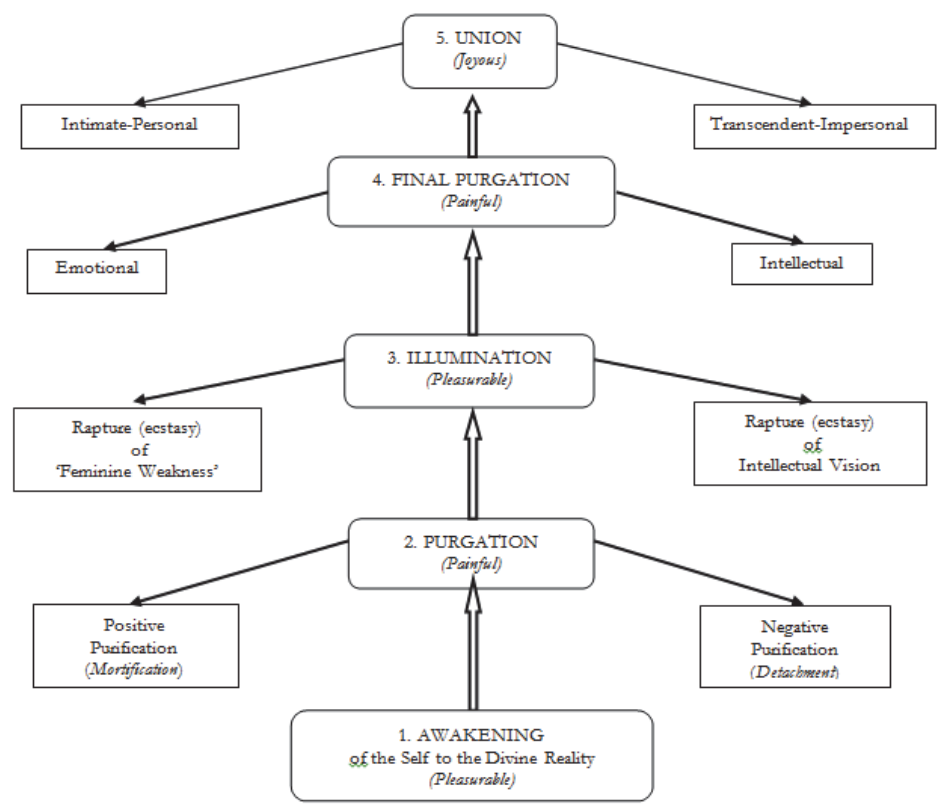

\section{Archetypal Exemplars in Christian Mysticism}

Given the nature and characteristics of Christian mysticism, it is not surprising to find that this area of human activity essentially bespeaks the subjectivist-empiricist or narrative-interpretive (type III) modality of mind.

The deeply personal spiritual experiences and way of life of true mystics are presented in various texts in which they describe the goals and activities of the 'mystic way' in the story-telling, poetical orientation of mind. They were not primarily philosophers (type I) or scientific theologians (type II, e.g., Aquinas), but people who also shared their mystical insights with the community of believers and others around them, in their sermons and on their journeys.

The main purpose of the present series of papers (Parts I, II and III) is to demonstrate that the theory of archetypal orientations of mind is supported in the area of Christian mysticism. A study of major figures in the history of Christian mysticism was conducted, as a result of which a number of exemplars of each of the four basic modalities of mind were identified for further analysis. The mystics chosen for inclusion are shown in Figure 10 below.

Gregory of Nyssa, Dionysius the Areopagite (also known as the Pseudo-Dionysius) and Meister Eckhart represent the objectivist-empyrean (type I) orientation, designated as 'speculative mysticism.' For the objectivist-empiricist (type II) modality of 'systematic mysticism,' Evagrius Ponticus, the anonymously authored Theologia Germanica and the Spanish mystic, John of the Cross were chosen as exemplars. Their writings will be addressed in Part II.

Richard Rolle, Henry Suso, and Madame Guyon are meta-theoretical representatives of the subjectivist-empiricist (type III) paradigm, referred to as 'poetical mysticism. This is also the overall orientation and approach of mystics in general.

Lastly, the subjectivist-empyrean (type IV) modality of 'pragmatic mysticism' is represented by John Tauler, the anonymously authored Cloud of Unknowing by an English mystic, and the work of the Spaniard, Miguel de Molinos. Altogether, the exemplars included for analysis represent a time-scale of about thirteen centuries, ranging from Gregory of Nyssa (born 335 CE) to Madame Guyon (born 1648 CE). The type III and IV meta-orientations will be discussed in Part III. 
Figure 10: Archetypal exemplars in Christian mysticism

\begin{tabular}{|l|l|}
\hline Type II: Systematic Mysticism & Type I: Speculative Mysticism \\
Evagrius Ponticus & Gregory of Nyssa \\
Theologia Germanica & Dionysius the Areopagite \\
John of the Cross & Meister Eckhart \\
\hline Type III: Poetical Mysticism & Type IV: Pragmatic Mysticism \\
Henry Suso & John Tauler \\
Richard Rolle & Cloud of Unknowing \\
Madame Guyon & Miguel de Molinos \\
\hline
\end{tabular}

\section{Summary}

This paper (Part I) described a general theory of human thought. Main propositions or theses of the theory were presented, followed by an outline of the nature and elements of Christian mysticism and the 'Mystic Way.'

In addition, a number of exemplars of Christian mysticism, over a period of more than a millennium in the history of Christianity, were identified as representative of each of the four modalities of mind. Speculative mysticism and Systematic mysticism (both reflecting the objectivist tendency) will be discussed in a separate paper (Part II), whilst Poetical and Pragmatic mysticism (the more subjectivist inclination) will be treated in a third paper (Part III).

\section{References}

Inge, W. R. (1904) Light, life and love: selections from the German mystics of the Middle Ages, Grand Rapids, Ml: Christian Classics Ethereal Library.

McGinn, M. (Ed) (2006) The essential writings of Christian mysticism, New York: The Modern Library.

Pietersen, H. J. (2011) The Four Types of Knowing -Metaphysical, Scientific, Narrative and Pragmatic: A Meta-Epistemology of Mind, New York: Edwin Mellen Press.

Pietersen, H. J. (2014) The Four Archetypal Orientations of the Mind: Foundational, Experiential, Organizational and Actional, New York: Edwin Mellen Press.

Underhill, E. (1920) The essentials of mysticism and other essays, Grand Rapids, MI: Christian Classics Ethereal Library.

Underhill, E. (1930) Mysticism: A study in the nature and development of spiritual consciousness, Grand Rapids, Ml: Christian Classics Ethereal Library. 